\title{
An Investigation of Macronutrient Intakes among Infants in Saudi Arabia
}

\section{Alzaheb $\mathbf{R}^{1 *}$ and Almotairi $\mathbf{M}^{2}$}

${ }^{1}$ Faculty of Applied Medical Science, University of Tabuk, Tabuk, Saudi Arabia

${ }^{2}$ The King Faisal Specialist Hospital and Research Centre, Riyadh, Saudi Arabia

\begin{abstract}
Toddlerhood is a vital phase of early life, during which long-term dietary habits are established. The aim of this study was to evaluate changes in dietary intake during the transition from baby food to table food in Saudi Arabia A three-day food diary was used to record food and beverage intake data, which was then analysed using Weighed Intake Software Program (WISP). The main finding of study was that there was a rapid increase in protein intake during the transition towards a family food diet. However, this was not the case with the intakes of carbohydrate and fat.
\end{abstract}

Keywords: Macronutrient intake; Protein; Toddle

\section{Introduction}

Nutrition in early life can have long-term effects on health in adulthood. There is now strong evidence that toddlerhood is a vital phase of early life, in which a person's long-term dietary habits are established. This potentially means that life-long levels of appetite, the likelihood of obesity, and other risk factors for cardiovascular diseases (CVD) are partly established at an early age [1]. It has been observed that scarce information is available on the impact of the transition from infant foods to table foods in terms of nutrient intake [2].

The main purpose of this study was to address this issue, by evaluating the changes in dietary intake during the early development stage of between 6 and 12 months in Saudi Arabia.

\section{Methods}

\section{Recruitment}

The study was done at the King Faisal Specialist Hospital, in Riyadh, Saudi Arabia. Its participants were 41 parents/caretakers of infants aged between 6 and 12 months. The fieldwork for the study was carried out between July 2011 and February 2012. Ethical approval was granted by King Faisal Specialist Hospital's Research Ethics Committee.

\section{Dietary records}

A three-day diet diary format was developed by the research team for use by the parents/caretakers of the infants and toddlers aged between six to 12 months. The types and amounts of drinks, the types of food (including the ingredients of homemade meals and the brand names of processed foods) and the amounts offered to and left by the child. At the end of the recording period, the researchers visited the homes to collect the records and check their completeness.

\section{Dietary calculations}

Each completed diary was transformed into weights and codes corresponding to each of the foods or beverages taken, using Weighed Intake Software Program (WISP) (Tinuviel Software, Anglesey, UK). The data entry procedure involved entering food codes with weights in grams, adding new codes for foods which were not already in the database. Homemade foods were sometimes reported in the diet diaries; in such instances, the recipe entry requested from the parent was used to determine their ingredients, after which these foods were added to the database. WISP also allowed the entry of the nutrient data of commercially manufactured products, based on information which was obtained from the product labels available online. Once all the foods and their weights were entered, the nutrient data were then imported into the SPSS for statistical analysis [3].

The volume of breast milk consumed was estimated for infants reported as breast feeding, using an approach recently used in the Diet and Nutrition Survey of Infants and Young Children, 2011 [4]. This estimated the amounts of breast milk consumed as $470 \mathrm{~g}$ and $400 \mathrm{~g}$, for infants aged 6 months and 12 months respectively.

\section{Statistical analysis}

Statistical analysis was performed using the SPSS for Windows statistical package (18.0; SPPS Inc., Chicago, IL., USA). All p-values were two-tailed, and statistical significance was considered to exist for $\mathrm{p}$-values of $<0.05$. Continuous variables (macronutrient intakes) were presented as mean and standard deviation (SD) and categorical variables were presented only as frequencies. An independent samples t-test evaluated changes in diet among infants.

\section{Results}

Figure 1 shows the differences in macronutrient intakes between 6 and 12 months. It is evident that the total energy intake (EI) and intakes of protein and carbohydrate (both in grams and as a percentage of total EI) increased with increasing age from 6 months to 12 months. Conversely, and as expected, Fat intake did not increase between the two ages, but instead decreased as a percentage of total EI (Figure 1).

Table 1 shows the differences in dietary intakes between the two age groups. From an intake of $848 \pm 177 \mathrm{kcal} /$ day at 6 months, EI had significantly increased by 12 months of age (1066 $\pm 249 \mathrm{kcal} /$ day $)$. It is also apparent that the absolute intakes of protein and carbohydrate followed a similar pattern, as they rose significantly between 6 and 12 months of age (for 6 and 12 months of age, respectively, the figures were: $19.5 \pm 6.7 \mathrm{~g} /$ day and $42.5 \pm 11.7 \mathrm{~g} /$ day for protein, $98.2 \pm 21.8 \mathrm{~g} /$

${ }^{*}$ Corresponding author: Riyadh Abdulrahman S Alzaheb, Department of Applied Medical Science, University of Tabuk, Tabuk, Saudi Arabia, Tel: 00966555543718; E-mail: ralzaheb@ut.edu.sa

Received March 31, 2015; Accepted April 11, 2015; Published April 16, 2015

Citation: Alzaheb R, Almotairi M (2015) An Investigation of Macronutrient Intakes among Infants in Saudi Arabia. J Nutr Disorders Ther 5: 157. doi:10.4172/21610509.1000157

Copyright: ( 2015 Alzaheb R, et al. This is an open-access article distributed under the terms of the Creative Commons Attribution License, which permits unrestricted use, distribution, and reproduction in any medium, provided the original author and source are credited. 

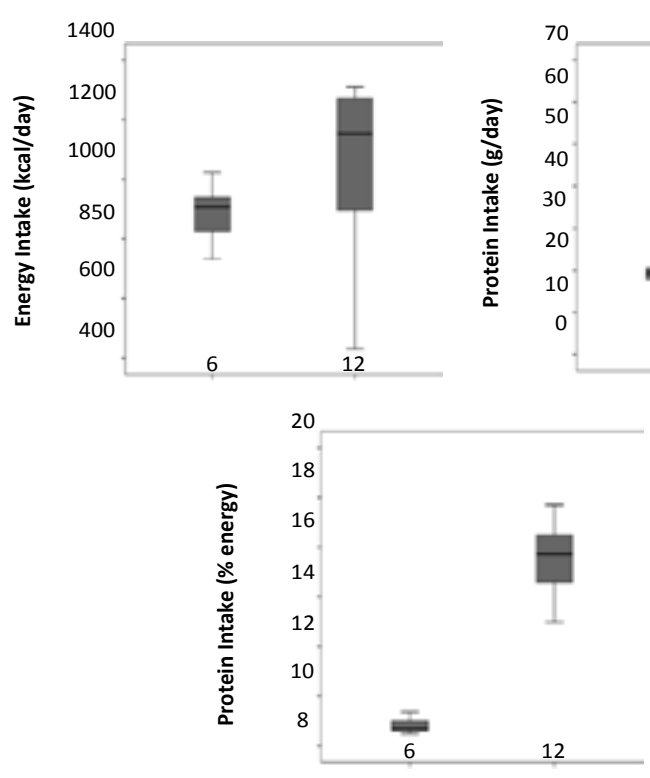
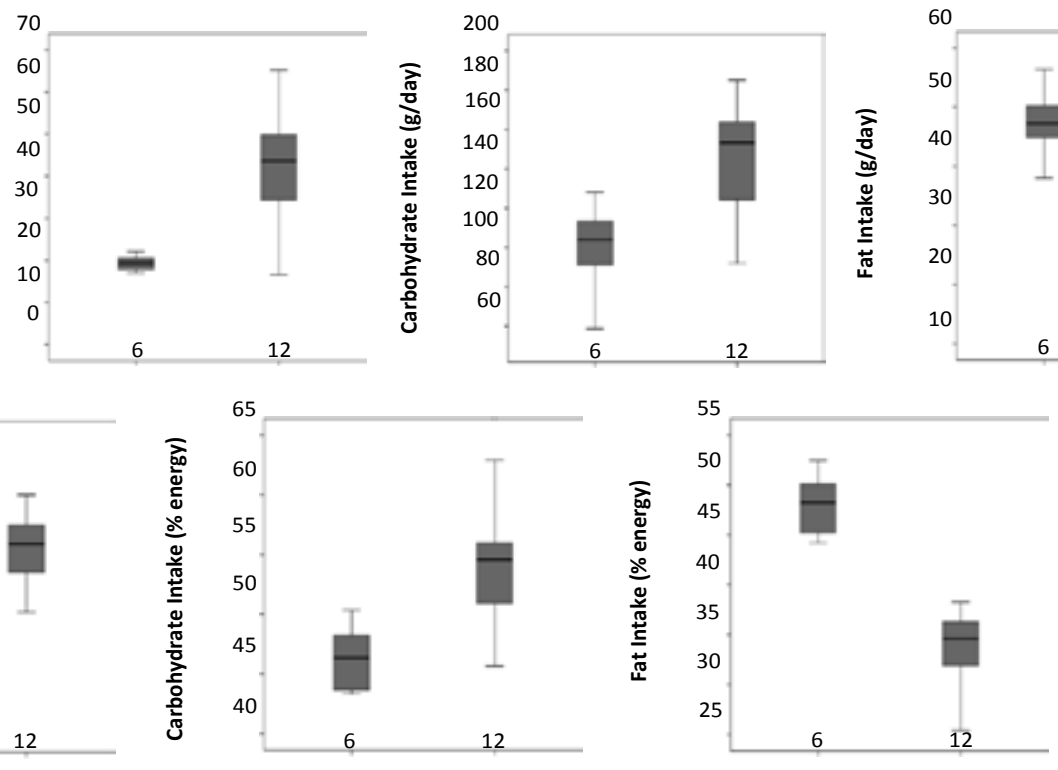

Age groups (months)

6 months $(\mathrm{n}=19)$

12 months $(\mathrm{n}=22)$

Figure 1: Boxplot showing the differences in dietary intake variables for infants at different ages $(n=41)$.

\begin{tabular}{|c|c|c|c|}
\hline & \multicolumn{2}{|c|}{ Age groups } & \multirow{2}{*}{$\mathrm{P}$} \\
\hline & 6months $(n=19)$ & 12 months $(n=22)$ & \\
\hline EI (kcal/day) & $848 \pm 177$ & $1066 \pm 249$ & .002 \\
\hline \multicolumn{4}{|l|}{ Absolute intake $^{1}$} \\
\hline Protein $(\mathrm{g})$ & $19.5 \pm 6.7$ & $42.5 \pm 11.7$ & $<.0001$ \\
\hline Carbohydrate (g) & $98.2 \pm 21.8$ & $144.6 \pm 30.8$ & $<.0001$ \\
\hline Fat $(\mathrm{g})$ & $45.1 \pm 8.9$ & $40.2 \pm 12.0$ & .145 \\
\hline \multicolumn{4}{|l|}{ Relative intake $^{2}$} \\
\hline Protein (\%) & $9.1 \pm 1.5$ & $15.9 \pm 1.8$ & $<.0001$ \\
\hline Carbohydrate (\%) & $46.3 \pm 2.5$ & $54.7 \pm 4.7$ & $<.0001$ \\
\hline Fat (\%) & $48.0 \pm 2.7$ & $33.5 \pm 3.9$ & $<.0001$ \\
\hline \multicolumn{4}{|c|}{$\begin{array}{l}\text { Abbreviation: El: Energy Intake. } \\
\text { All values Mean } \pm \text { SD. } \\
\text { The independent samples t-test. } \\
{ }^{1} \text { Expressed as grams per day. }\end{array}$} \\
\hline
\end{tabular}

Table 1: Significant differences in dietary intakes at 6 and 12 months $(n=41)$.

day and $144.6 \pm 30.8 \mathrm{~g} /$ day for carbohydrate). The fat intake differed, as it shows a non-statistically significant decrease between the two ages. However, when intakes of the macronutrients are expressed as a percentage of EI, only protein and carbohydrate showed increases with increasing age from 6 to 12 months, while in contrast, fat showed a significant decrease (for 6 and 12 months, respectively, the figures were: $9.1 \%$ and $15.9 \%$ for protein, $46.3 \%$ and $54.7 \%$ for carbohydrate and $48.0 \%$ and $33.5 \%$ for fat) (Table 1 ).

When comparing mean protein intake with the WHO average requirements and safe levels for protein [5], Figure 2 demonstrates that the average daily intake of protein exceeded requirements for the two age groups. Specifically, infants aged 6 months and 12 months respectively consumed about 2.0 and 3.9 times more protein relative to the WHO requirements (Figure 2).

\section{Discussion}

The main findings of the Saudi study were as follows. When macronutrient intakes were expressed as absolute amounts, the mean intakes of energy, protein and carbohydrate rose significantly between 6 and 12 months of age. However, when intakes of the macronutrients were expressed as a percentage of EI, protein and carbohydrate showed increases with increasing age. These findings can be compared with a study by [2] which also collected information on actual dietary intake in order to evaluate changes in the mean intakes of nutrients during the transition from baby food to table food, for older infants and toddlers aged between nine to 11 months $(n=679), 12$ to 14 months $(n=374)$, 15 to 18 months $(n=308)$, and 19 to 24 months $(n=316)$. They found that the mean intakes of energy, protein, carbohydrate and total fat increased with age. 
Citation: Alzaheb R, Almotairi M (2015) An Investigation of Macronutrient Intakes among Infants in Saudi Arabia. J Nutr Disorders Ther 5: 157. doi:10.4172/2161-0509.1000157

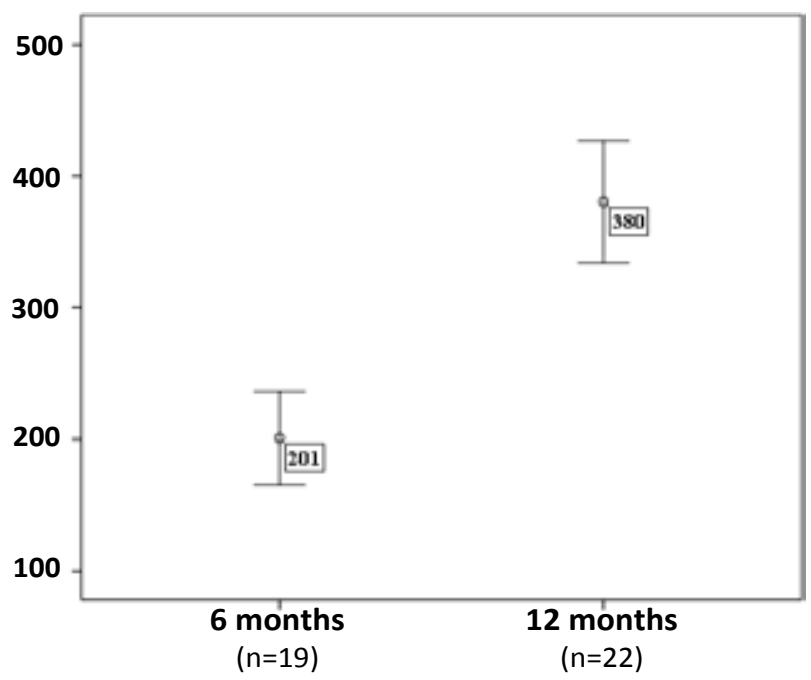

Figure 2: Mean protein intakes (with 95\% confidence limits) as a percentage of the World Health Organization (WHO) requirements ( $\mathrm{n}=41$ ).

The findings of the study also show that there was a rapid increase in protein intake with increasing age not only when the intake of protein was measured in absolute terms as grams but also when the intake was measured as a percentage of the total EI. These findings are consistent with a number of other follow-up studies which have reported that it is common for infants to experience a rapid rise in their protein intake during the introduction of solid foods and during the transition towards a family food diet $[5,6]$. For example, a follow-up study conducted by Gunther et al. in Germany found that for infants of 6 months, 12 months, and toddlers of 18-24 months of age, the mean daily protein intakes were $11.9 \mathrm{~g} /$ day, $29.7 \mathrm{~g} /$ day and $33.8 \mathrm{~g} /$ day respectively. The mean percentages of energy from protein were $7.8 \%$, $14.7 \%$ and $14.8 \%$ respectively.

Continuing the consideration of the context of the study in relation to the research in the field, a number of prior longitudinal studies have also shown a positive association between a high protein intake during infancy and early childhood and a higher BMI in later childhood [5,712]. For example, a recent follow-up study observed that a higher protein intake at an age of 18 months was positively associated with a higher BMI at 8 years of age [7].

A number of limitations are inherent in the study, and these should be acknowledged. The first limitation is that the data gathered were cross-sectional in design and therefore did not follow the same children's intakes at different stages in their development. The second limitation of the study was the non-representativeness of the investigated samples as the sample was relatively small. Given the above-mentioned shortcomings, caution should be exercised in drawing definitive conclusions and in generalising the results of the Scottish or Saudi studies to the wider populations.

\section{Acknowledgments}

We would like to thank the participating children and families and special thanks to Meshal Almotairi for his help with the data collection. Additionally we would like to thank to staff at the King Faisal Specialist Hospital for their help and support on this project.

\section{Reference}

1. Lanigan J, Singhal A (2009) Early nutrition and long-term health: a practical approach. Proc Nutr Soc 68: 422-429.
2. Briefel RR, Reidy K, Karwe V, Jankowski L, Hendricks K (2004) Toddlers' transition to table foods: Impact on nutrient intakes and food patterns. J Am Diet Assoc 104 (1 Suppl): s38-s44.

3. Lennox A, Sommerville J, Ong K, Henderson H, Allen R (2011) Diet and nutrition survey of infants and young children.

4. World Health Organization (2007) Protein and amino acid requirements in human nutrition: WHO Technical Report Series (935).

5. Gunther AL, Buyken AE, Kroke A (2007a) Protein intake during the period of complementary feeding and early childhood and the association with body mass index and percentage body fat at $7 \mathrm{y}$ of age. Am J Clin Nutr 85: 16261633.

6. Gunther AL, Remer T, Kroke A, Buyken AE (2007b) Early protein intake and later obesity risk: which protein sources at which time points throughout infancy and childhood are important for body mass index and body fat percentage at 7 y of age? Am J Clin Nutr 86: 1765-1772.

7. Garden FL, Marks GB, Almqvist C, Simpson JM, Webb KL (2011) Infant and early childhood dietary predictors of overweight at age 8 years in the CAPS population. Eur J Clin Nutr 65: 454-462.

8. Gunnarsdottir I, Thorsdottir I (2003) Relationship between growth and feeding in infancy and body mass index at the age of 6 years. Int $\mathrm{J}$ Obes Relat Metab Disord 27: 1523-1527.

9. Gunther AL, Buyken AE, Kroke A (2006) The influence of habitual protein intake in early childhood on BMI and age at adiposity rebound: results from the DONALD Study. Int J Obes (Lond) 30: 1072-1079.

10. Ohlund I, Hernell O, Hornell A, Stenlund H, Lind T (2010) BMI at 4 years of age is associated with previous and current protein intake and with paternal BMI. Eur J Clin Nutr 64: 138-145.

11. Rolland-Cachera MF, Deheeger M, Akrout M, Bellisle F (1995) Influence of macronutrients on adiposity development: a follow up study of nutrition and growth from 10 months to 8 years of age. Int J Obes Relat Metab Disord 19: 573-578.

12. Verduci E, Radaelli G, Stival G, Salvioni M, Giovannini M, et al. (2007) Dietary macronutrient intake during the first 10 years of life in a cohort of Italian children. J Pediatr Gastroenterol Nutr 45: 90-95. 